\title{
Śpiewać niewyśpiewalne? Miejsce musicalu w edukowaniu o Holokauście
}

Podlałem kwiaty, biedne rośliny sierocińca, rośliny żydowskiego sierocińca. - Ziemia spieczona odetchnęła. Przyglądał się mojej pracy wartownik. Czy go drażni[,] czy rozrzewnia ta moja pokojowa o szóstej rano czynność?

Stoi i patrzy. Nogi szeroko rozstawił [...].

Nie wiem, jak czuje i czym czuje się żołnierz armii zwycięskiej... [...]

Nikomu nie życzę źle. Nie umiem. Nie wiem, jak to się robi. [...]

Co by zrobił, gdybym mu kiwnął głową? - Przyjaźnie ręką pozdrowił? Może on nie wie nawet, że jest tak, jak jest? Mógł przyjechać wczoraj dopiero z daleka...

J. Korczak: Pamiętnik... ${ }^{1}$

\section{$5 \mathrm{xP}$}

Teatr jako doświadczenie przemieniające

Elie Wiesel zapytany o drogi wiodące do naprawy świata udzielił odpowiedzi: „Edukacja i pamięć”. Dodawał też, że nie wierzy w krzyki, raczej w szept: „Nigdy nie podnoszę głosu, to nie pomaga. Król Salomon przekazał prawdę, że jeśli mówisz łagodnie, zostaniesz usłyszany"3. W niniejszym artykule interesuje mnie rola edukacji teatralnej w nauczaniu o Zagładzie, edukacji, w której me-

\footnotetext{
${ }^{1}$ J. Korczak: Pamiętnik i inne pisma z getta. Przypisy M. Ciesielska. Posłowie J. Leociak. Warszawa 2012, s. 136-140.

${ }^{2}$ Holocaust Survivor, Peace Prize Winner Talks to Local High School and College Students. Dostępne w Internecie: https://www.daytondailynews.com/news/local/elie-wiesel-the-answeredu cation-and-memory/XME3lf3TQTDmQmboHzDFuL/ [data dostępu: 18.11.2018]. Tłumaczenie własne - J.R.

3 Tamże.
} 
dium staje się nie szept, ale dźwięk. Przedmiotem namysłu będą bowiem dwa musicale.

„[...] nie chcę sprowadzać na świat dzieci, które zabije jedna z przyszłych wojen" - deklarowała Tove Jansson. W Lecie Muminków pisała zaś: „Teatr jest najważniejszą rzeczą na świecie, gdyż tam pokazuje się ludziom, jakimi mogliby być, jakimi pragnęliby być, choć nie mają na to odwagi,

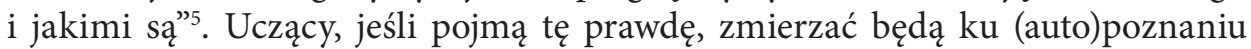
wychowanków przez ich konfrontację $\mathrm{z}$ teatrem, także teatrem musicalowym ${ }^{6}$, zapewniającym głębokie przeżycie ${ }^{7}$ i wspierającym postawy twórcze ${ }^{8}$. Podczas gdy dramatyzowanie poświęconych Zagładzie lekcji języka polskiego bywa rozważane jako nieetyczne, teatr stwarza potencjalność głębokiego przeżycia per se. Ponadto daje dzieciom i młodzieży czas na refleksję i umożliwia wnikanie $\mathrm{w}$ motywacje różnych postaci? .

Kenowi Robinsonowi, jak i wszystkim innym nauczycielom wprowadzającym elementy edukowania na rzecz pokoju (ponieważ nauczanie o Holokauście należy postrzegać jako składową tego obszaru), bliskie jest spojrzenie na lekcję i szkołę jako "doświadczenie przemieniające"10. Pisząc o nim, autorzy książki Kreatywne szkoły... przywoływali Petera Brooka, który uważał, że doskonalenie się w aktorstwie jest równoznaczne z doskonaleniem się jako człowiek. Doskonalenie się w byciu widzem oznacza to samo - wychowanie empatyczne, budowanie przez edukację teatralną inteligencji emocjonalnej. Teatr może wychować młodych ludzi, którzy w sytuacji wymagającej ich reakcji wyjdą z bezpiecznej roli gapia.

Do grupy prekursorów edukujących na rzecz pokoju należał Janusz Korczak, jeden z bohaterów dalszej części artykułu: zrewolucjonizował on system nauczania, a także oparł prowadzoną placówkę na ideałach pokoju, na relacyjności i inspiracji podopiecznych do życia $\mathrm{w}$ duchu poszanowania każdego członka

${ }^{4}$ B. Westin: Tove Jansson. Mama Muminków. Biografia. Przeł. B. Ratajczak. Warszawa 2012, s. 117.

5 T. Jansson: Lato Muminków. Przeł. I. Szuch-Wyszomirska. Warszawa 1967, s. 116.

${ }^{6}$ Zob. A. Bielańska: Teatr, który leczy. Kraków 2002; A. Hannowa: Młodzież i teatr. Warszawa-Wrocław 1990; M. KwiAткоwsкı: Uruchomić wyobraźnię. „Polonistyka” 1995, nr 9, s. 612-615; W. PANeK: Musical i rozrywkowy teatr muzyczny. „Wychowanie Muzyczne w Szkole” 1999, nr 1, s. 147-152.

7 W.P. ZaCZyŃski: Uczenie się przez przeżywanie. Warszawa 1990.

${ }^{8}$ R. Miller: Z rozważań nad edukacją teatralną. „Kwartalnik Pedagogiczny” 1968, nr 3, s. 136 (przedruk za: Więcej niż teatr. Sztuka zaangażowania i angażujaca wychowawczo. Romany Miller inspiracje dla współczesnej pedagogiki. Red. M. Szczepska-Pustrowska, E. Rodziewicz. Gdańsk 2017, s. 58-76).

9 Zob. B. Krupa: Czy zajęcia o Zagładzie moga/powinny być atrakcyjne. W: Auschwitz i Holokaust: dylematy i wyzwania polskiej edukacji. Red. P. Trojański. Oświęcim 2008.

${ }^{10}$ K. Robinson, L. Aronica: Kreatywne szkoty. Oddolna rewolucja, która zmienia edukację. Przeł. A. BAJ. Kraków 2015, s. 103. 
rodziny ludzkiej. W tetradzie Betty Reardon, uznającej za fundamenty idealnej edukacji na rzecz pokoju to, co: personalne, polityczne, pedagogiczne i poetyckie $^{11}$, można by dodać adiekcji jeszcze jednego P - performatywnego. Warto rozważyć je w zespoleniu z najmniej oczywistym elementem wskazanym przez amerykańską badaczkę: poetyckim. Literatura, w tym również poezja (a musicalowemu librettu najbliżej przecież do cech gatunku poetyckiego, piosenka zaś jest nim per se), może stać się narzędziem doskonalenia się młodych ludzi w człowieczeństwie.

Prym w polonistycznym nauczaniu o Zagładzie należy przyznać esejowi, poezji i powieści - ich wykorzystanie doczekało się niedawno dwóch ciekawych studiów: Małgorzaty Wójcik-Dudek W(y)czytać Zagładę... oraz Agnieszki Kani Lekcja (nie) obecności. Dziedzictwo polsko-żydowskie w edukacji polonistycznej ${ }^{12}$. W tym artykule interesuje mnie pokojowy akt recepcji teatralnej, gdy współkonstytuującymi staną się dzieci, niepomiernie rzadziej wykorzystywany w Polsce w edukowaniu na temat Holokaustu i tego, jak do niego doszło oraz jakie miał i obecnie ma konsekwencje.

Andy Pearce i Arthur Chapman zauważają w szkicu The Holocaust in the National Curriculum after 25 Years, osadzonym w realiach brytyjskich ${ }^{13}$, że uczniów wcześniejszych klas szkoły podstawowej wprowadza się w temat Zagłady, zapoznając ich ze zjawiskami kulturowymi - przy czym szczególną rolę wśród filmów i powieści autorzy przypisują tu obrazowi Chłopiec w pasiastej piżamie i książce Johna Boyne’a ${ }^{14}$, na podstawie której ów powstał (nierzadko wyświetla się go podczas lekcji także w polskich szkołach - podobnie jak Życie jest piękne $e^{15}$ $\mathrm{i}$ - w klasach licealnych - Pianistę $\left.{ }^{16}\right)$. Zwracają też uwagę na edukowanie na temat Holokaustu jako trend w przedszkolach, co określają „kontrowersyjnym i niepopartym jeszcze badaniami empirycznymi"17.

${ }^{11}$ Higher Education for Peace. Report. Conference in Tromso, 4-6 May 2000.

${ }_{12}$ M. Wójcik-Dudek: W(y)czytać Zagładę. Praktyki postpamięci w polskiej literaturze XXI wieku dla dzieci i młodzieży. Katowice 2016; A. Kania: Lekcja (nie) obecności. Dziedzictwo polsko-żydowskie w edukacji polonistycznej. Kraków 2017.

${ }^{13}$ Zob. S. Foster et al.: What Do Students Know and Understand about the Holocaust? Evidence from English Secondary Schools. London 2015; A. Pettigrew et al.: Teaching about the Holocaust in English Secondary Schools: An Empirical Study of National Trends, Perspectives and Practice. London 2009.

${ }^{14}$ J. Boyne: Chłopiec w pasiastej piżamie. Przeł. P. Łopatka. Poznań 2017. Adaptacja filmowa: Reż. i scen. M. Herman. USA-Wielka Brytania 2008.

${ }_{15}$ Życie jest piękne. Reż. R. Benigni. Scen. R. Benigni, V. Cerami. Włochy 1997.

${ }_{16}$ Pianista. Reż. R. Polański. Scen. R. Harwood. Francja-Niemcy-Polska-Wielka Brytania 2002.

17 A. Pearce, A. Chapman: The Holocaust in the National Curriculum after 25 Years. "Holocaust Studies. A Journal of Culture and History" 2017, no 23, s. 225. 


\section{Musical i ocalanie człowieczeństwa}

"Głupawe tancerki w tandetnych kieckach" - charakteryzuje formę musicalu jeden $\mathrm{z}$ bohaterów Producentów $\mathrm{w}$ reżyserii Mela Brooksa ${ }^{18}$. Komedia o parze hochsztaplerów to tekst subwersywny i tym samym każe dostrzegać w przytoczonym zdaniu również definicję à rebours. Inscenizacje, którymi się tu zajmę - Korczak oraz Imagine This (omówiony raczej szkicowo, także przez wzgląd na niedostępność tekstu dla polskich czytelników) - z takim postrzeganiem musicalu nie mają nic wspólnego ${ }^{19}$. Brak w nich blichtru, dotykają wątku ocalania człowieczeństwa $\mathrm{w}$ sytuacji in extremis - w czasie Zagłady ${ }^{20}$. Właśnie stereotypowe wyobrażenie musicalu jako rozrywki łatwej i przyjemnej wywołało sceptyczną postawę wobec przygotowania przez Chrisa Williamsa, autora muzyki do Korczaka, musicalu na tak znaczący temat, jak Holokaust ${ }^{21}$.

Imagine This oraz Korczak okazują się zresztą wielorako łączliwe, między innymi przez motyw teatru $\mathrm{w}$ teatrze ${ }^{22}$. Taka konstrukcja dramatyczna, prowadząca do podwojenia rzeczywistości scenicznej, odwzorowująca relację scena widownia, kieruje $\mathrm{w}$ trzy różne sfery: 1) do refleksji na temat samego tworzywa teatralnego, 2) do ponownego przemyślenia tematu ukazywalności Zagłady oraz 3) do podjęcia anonsowanego już wątku gapiów. Potraktuję je powierzchownie, skupiając się na zagadnieniu edukacji propokojowej prowadzonej torem musicalowym ${ }^{23}$.

${ }^{18}$ Libretto, muzyka i słowa piosenek: Mel Brooks, współpraca: Thomas Meehan (libretto) i Glen Kelly (orkiestracje).

${ }_{19}$ Nie trzeba przypominać, że Max Bialystok i Leo Bloom po poszukiwaniu ostentacyjnie złego scenariusza przedstawienia wybierają sztukę nazisty Franza Liebkinda pt. Wiosna dla Hitlera.

${ }^{20}$ Temat ten podjęła J. Hillman: Echoes of the Holocaust on the American Musical Stage. Jefferson 2012.

${ }^{21}$ Badanie wątku Holokaustu czy żydowskiego losu można by poszerzać o kolejne tytuły, np. o Dźwięki muzyki w reżyserii Roberta Wise’a, nagrodzony Oscarem dla najlepszego filmu, którego kanwą stała się autobiografia arystokratki Marii von Trapp, także zresztą uruchamiający tropy istotne w kontekście edukowania na rzecz pokoju. Do musicali podejmujących to zagadnienie należą Ragtime (1996, na podstawie książki E.L. Doctorowa, muzyka: Stephen Flaherty) i The Rothschilds, który powstał na podstawie książki Shermana Yellena, z librettem Sheldona Harnicka i muzyką Jerry’ego Bocka jako ostatnie ich wspólne dzieło, Milk and Honey (muzyka i libretto: Jerry Herman), Ghetto Joshui Sobola (przedstawienie muzyczne powstałe w 1984 r., prezentujące piosenki z getta wileńskiego).

${ }^{22}$ Zob. S. Świontek: Dialog, dramat, metateatr. Z problemów teorii tekstu dramatycznego. Warszawa 1999.

${ }^{23}$ O motywie play within the play ('spektakl wewnętrzny') zob. E. WĄchockA: Teatr $w$ teatrze. W: Encyklopedia teatru polskiego. Dostępne w Internecie: http://www.encyklopediateatru.pl/ hasla/180/teatr-w-teatrze [data dostępu: 18.11.2018]. 


\section{Coś więcej niż aktorzy - bo dzieci (Korczak)}

Europejskie Centrum Sztuki w Białymstoku, ulokowane na terenie byłego getta, w 2012 roku zainaugurowało działalność w nowym gmachu musicalem Korczak $^{24}$, opartym na dziele stworzonym w 1998 roku przez parę Brytyjczyków: Nicka Stimsona, który historię Starego Doktora poznał w latach 90. XX wieku podczas pobytu w Polsce, i Chrisa Williamsa. Skupili się oni na ostatnich tygodniach z życia autora Jak kochać dziecko i jego podopiecznych, przeplatając wydarzenia z roku 1942 scenami wakacyjnych kolonii, retrospekcjami sprzed wojny.

Kazimierz Dębnicki biografię Korczak $z$ bliska otworzył fragmentem nadającym jego narracji klamrową kompozycję i rzucającym światło na koncept autorów musicalu:

Zakończenie opowieści Janusza Korczaka o koloniach letnich dla dzieci żydowskich - Jośki, Mośki i Srule zawiera wstrząsającą refleksję. Wstrząsającą dzisiaj. Pisze Korczak: „A może nie wracać do Warszawy? Może ustawić się parami, wziąć chorągiewki, zaśpiewać marsza i ruszyć w drogę?

- Dokąd?

- Do Słońca.

Długo iść będzie trzeba. Ale cóż to szkodzi?"25.

Podobną klamrę zastosowali także twórcy spektaklu. Korczak zaczyna się obrazem chóru dzieci w komorze gazowej. Stary Doktor wyśpiewuje im eufemistycznie jako ojciec kładący je do snu:

Śpij

Śpij

Spij najgłębszym snem ${ }^{26}$.

Sięgnięcie po tworzywo biografii Korczaka jest równoznaczne z mierzeniem się z auratyczną legendą. Joanna Olczak-Ronikier napisała:

Krąży opowieść, że Doktor tuż przed wejściem do pociągu został rozpoznany przez Niemców i że zaproponowano mu ocalenie pod warunkiem, że zostawi dzieci. Odmówił. Ta odmowa uznawana jest za wyraz ostatecznego heroizmu. Ma świętą rację Henryk Grynberg, kiedy się irytuje: „Te przemówienia i pogadanki o jego heroicznej śmierci, bo nie chciał opuścić dzieci w drodze do

${ }^{24}$ Przedstawienie zostało objęte patronatem UNESCO. Znaczące, że plakat do niego stworzył Ryszard Horowitz, który jako dziecko przeżył Holokaust.

${ }^{25}$ K. DęвNıcKi: Korczak $z$ bliska. Warszawa 1985, s. 7.

${ }^{26}$ Za libretto musicalu Korczak (przeł. M. Hermansdorfer, T. Pstrokoński-Nawratil) dziękuję dr hab. Joannie Maleszyńskiej; plik bez numeracji stron. 
komór gazowych i żyć jakby nigdy nic - to największa zniewaga dla jego szlachetnej duszy"27.

Krakowska autorka zamknęła książkę zdaniem: „W żadnych dokumentach nie został ślad po sierpniowym transporcie dzieci z Krochmalnej”28. Przypominanie ich historii to próba przeciwstawienia się projektowi wymazania $\mathrm{z}$ pamięci Starego Doktora, jego dzieci i wszystkich innych żydowskich mieszkańców Europy $^{29}$.

W musicalowej opowieści utkanej ze scen z Domu Sierot przeważają motywy ptaków, wielorako antycypujące historię dzieci. Jak w scenie w drugim akcie, w której Staszek karmi okruchami trzymanego za oknem ptaka. Przytoczona rozmowa Pawła ze Staszkiem także prefiguruje ich los:

Paweł: Ptaki są najbardziej nieśmiałymi spośród boskich stworzeń. Pułapka gotowa. Teraz trzeba je do niej zwabić.

(Paweł zaczyna grać na piszczałce. Podchodzi ptak).

Scena ta staje się sui generis wariantem przekazu o szczurołapie z Hameln, z którym Korczak zapoznaje podopiecznych. W odsłonie pt. Flecista opowiada im znaną niemiecką historię ludową: w jej finale dzieci trafiają do kryształowej góry, gdzie zamiera czas. „Flecista zagrał inną melodię i poszły za nim wszystkie dzieci z Hameln. Zabrał je do kryształowej góry, gdzie nigdy się nie zestarzeją [...]”. Nieco dalej didaskalia informują: "Zatrzymuje się cała akcja, jakby patrzono w przyszłość".

Korczak został w musicalu ukazany jako pacyfista - wypowiada słowa: "To będzie moja trzecia wojna i każda do tej pory skończyła się klęską". Sven Hartman słusznie zauważył, że jego dzieło może być rozpatrywane także jako projekt pokojowy ${ }^{30}$. Stary Doktor wykreowany został ponadto na wskrzesiciela dorosłego dzieciństwa. Przy piosence ze sceny finałowej, zatytułowanej Być jeszcze raz dzieckiem - czytamy w tekście pobocznym: „Zakłada na głowę dziecięcą czapkę i bardzo ostrożnie rusza w mały galop, cicho rżąc. Rozgląda się wokół, zawstydzony swoim powrotem do dzieciństwa. Po chwili zyskuje pewność siebie i ponownie galopuje i rży". Takie sceny znajdują potwierdzenie we wspomnieniach świadków znających Korczaka. Roman Bertisch wydobył z pamięci obraz: „Zaskoczenie ogromne: po poręczy schodów zjeżdżają dzieci, a wśród nich, także na poręczy, niepozorna figurka dorosłego"31.

27 J. Olczak-Ronikier: Korczak. Próba biografii. Warszawa 2011, s. 431.

28 Tamże, s. 433.

29 Tamże, s. 9.

${ }^{30}$ S. Hartman: Janusz Korczak's Legacy: An Inestimable Source of Inspiration. In: J. Korczak: The Child's Right to Respect. Transl. E.P. Kulawiec. Strasbourg Cedex 2009, s. 16.

${ }^{31}$ R. Bertisch: Niepowtarzalny pedagog. W: Wspomnienia o Januszu Korczaku. Wybór i oprac. L. BArszczewska, B. Milewicz. Warszawa 1981, s. 198. 
Co dzieje się z dziedzictwem Korczaka - jego myślą pedagogiczną, proklamowanym stosunkiem do dzieci, postrzeganiem aktu nauczania - gdy sferą doświadczenia staje się przede wszystkim muzyka współtworzona przez same dzieci? Jak oddziałuje ten fakt na ranę po dzieciach Starego Doktora?

W scenie pt. Obietnica Korczak ukazany został podczas wykładu Serce dziecka. Po prześwietleniu podopiecznej, Dory, aparatem rentgenowskim przekazuje on słuchającym naukę:

Poproszono mnie dzisiaj, żebym wam pokazał, jak pracuje ludzkie serce, ale nie interesuje mnie anatomia. Interesują mnie wyłącznie uczucia, zwłaszcza jedno. Strach. Przyjrzyjcie się uważnie prześwietleniu i nigdy nie zapomnijcie tego widoku.

Przejmująco przeplatają się monologi Dory i Korczaka. Dalej cytuję tylko jego kwestie, przez ekwiwalencję rytmiczną stylizowane zresztą przedrzeźniająco na ceremoniał musztry i wojskowe komendy („na prawo patrz"):

Uważnie patrz,

Jak bije serce dziecka.

[...] Na dziecko patrz,

Na szybkość pulsu patrz,

Na krew wzburzoną patrz.

[...] na krótki oddech patrz.

[...] na łomot w piersi patrz,

$\mathrm{Na}$ lęk rosnący patrz.

[...] Nie zapomnijcie nigdy tego widoku! Zanim podniesiecie na dziecko rękę, zanim wymierzycie jakąkolwiek karę, przypomnijcie sobie, jak wygląda przerażone serce dziecka!

Ów wykład Doktor wygłosił w Państwowym Instytucie Pedagogiki Specjalnej. W pracowni rentgenowskiej zjawił się, inaczej niż w musicalu, $\mathrm{z}$ chłopcem obawiającym się nowego otoczenia, nieznanych ludzi, badania. Obraz jego zatrwożonego serca Korczak polecił studentom zapamiętać do końca życia. Dlaczego warto o tym wspomnieć? Ponieważ jakkolwiek edukacja propokojowa nie jest podejściem nowym, wciąż takim zdaje się wielu nauczycielom polskich szkół oraz badaczom przestrzeni szkolnej (świadczy o tym także brak polskojęzycznych opracowań naukowych ${ }^{32}$ ). Znaczy to, że pewne jej kluczowe postulaty od lat funkcjonują tylko jako nierealizowane dezyderaty.

W obsadzie musicalu znalazła się blisko setka dzieci, równolatków wychowanków Korczaka. Czy młodzi aktorzy na scenie białostockiej filharmonii znali

${ }^{32}$ Zob. J. Leek: Pomiędzy porozumieniem a zrozumieniem. Wyzwania edukacji na rzecz pokoju. „Studia Dydaktyczne” 2014, T. 26, s. 247-257. 
historię o wystawieniu przez dzieci z warszawskiego sierocińca własnego przedstawienia, Poczty Rabindranatha Tagore’a, na trzy tygodnie przed śmiercią ${ }^{33}$ ? Młodych aktorów i młode aktorki przygotowała Estera Winogronówna - opiekunka w Domu Sierot Korczaka, zafascynowana baletem studentka Uniwersytetu Warszawskiego. Joanna Olczak-Ronikier dodaje: „Zdawała sobie sprawę, że nie ma szans $w$ tej dziedzinie. $Z$ tym większą pasją zajmowała się zespołem tanecznym Domu i organizowała najrozmaitsze wydarzenia teatralne"34.

Jak zatem czuły się dzieci, które odgrywały los ich rówieśników, a nierzadko też imienników i imienniczek, okradzionych z życia, jak wnikały w tę niesymetryczność ich losów? Stary Doktor - bohater historii Adama Jaromira poświęconej wystawieniu tego spektaklu - myśli: „Może ta właśnie bajka zdoła nadać temu życiu jakiś sens i przygotować dzieci do tej długiej, dalekiej i niebezpiecznej podróży" ${ }^{35}$. W musicalu przygotowuje ich na to opowieścią o szczurołapie z Hameln.

Obie historie - i Poczta, i ludowy przekaz o szczurołapie - przełamują tabu śmierci i ukazują podróż do dalekiego kraju. 18 lipca 1942 roku wraz z wystawieniem Poczty w sierocińcu wydarzyło się misterium oczekiwania na dramat Zagłady $^{36}$.

Na zaproszeniu widniały słowa Janusza Korczaka:

Nie jesteśmy skłonni obiecywać, nie mając pewności.

Pewni jesteśmy, że godzina pięknej bajki myśliciela i poety da wzruszenie „najwyższego szczebla" drabiny uczuć ${ }^{37}$.

I dalej przytoczono słowa Władysława Szlengla, które odnieść można także do młodych aktorów z Białegostoku:

Coś więcej niż tekst - bo nastrój,

Coś więcej niż emocja - bo przeżycie,

Coś więcej niż aktorzy - bo dzieci.

Ideały autora sztuki, indyjskiego poety i pacyfisty, Rabindranatha Tagore’a jak rekonstruuje Joanna Olczak-Ronikier:

Opierały się na bliskim mu [Korczakowi - J.R.] przekonaniu, że tylko poprzez prawidłowe wychowywanie dzieci można doprowadzić ludzkość do przemia-

${ }^{33}$ Jej elementy wykorzystał w (A)polonii Krzysztof Warlikowski.

${ }^{34}$ J. Olczak-Ronikier: Korczak..., s. 371.

35 A. Jaromir: Ostatnie przedstawienie panny Esterki. Il. G. Cichowska. Poznań 2014 (bez numerów stron).

${ }^{36}$ Zob. R. Tagore: Poczta. Przeł. B. Gebarski. Posłowiem opatrzył R. Waksmund. Wrocław 1997.

${ }^{37}$ Cyt. za: J. Olczak-Ronikier: Korczak..., s. 409. 
ny duchowej, do przebudowy stosunków społecznych i politycznych, w konsekwencji do harmonii w świecie.

Nie były to teorie nowe. To samo głosił Rabindranath Tagore, indyjski poeta, prozaik, filozof, kompozytor, malarz, a także pedagog, który w roku 1901 założył w Zachodnim Bengalu, w lesie, w odosobnieniu od świata eksperymentalną szkołę, którą nazwał Przystań Pokoju. Kładziono w niej nacisk na poznawanie siebie, pracę nad sobą, harmonijne łączenie rozwoju duchowego, intelektualnego, społecznego i fizycznego, wpajanie szacunku dla wszystkich istot żyjących. [...] Podobny system Korczak próbował realizować w Domu Sierot ${ }^{38}$.

Kto zna tę autentyczną historię o wystawieniu przez Korczakowskie dzieci Poczty, patrząc na białostockie dzieci na scenie, może mieć złudzenie odgrywania tamtego właśnie spektaklu, co - okrężną drogą - czyni musical autotematycznym, przywołuje wydarzenia z 18 lipca 1942 roku i stwarza kolejną ramę dla opowieści.

\section{Wyobrazić niewyobrażalne Imagine This ${ }^{39}$}

Tytuł musicalu - Imagine This, z muzyką Shuki Levy'ego, urodzonego w 1947 roku izraelsko-amerykańskiego kompozytora i producenta, ze słowami Davida Goldsmitha ${ }^{40}$ - wysyła skojarzenia odbiorcy w kilka kierunków: między innymi do znanej piosenki pacyfistycznej Johna Lennona Imagine, ponadto anonsuje temat reprezentacji Zagłady ${ }^{41}$. Jej badacz, Jean-Luc Nancy - za Maurice’em Blanchotem - nazwał wyrwę w niej absensem, czymś „szczególnie unerwionym” ${ }^{2}$. Owo szczególne unerwienie towarzyszy musicalowi podejmującemu temat Holokaustu i obrazującemu śmierć właśnie jako wyrwę, absens. Takie rozwiązanie przyjęto i w Korczaku, i w Imagine This.

38 Tamże, s. 234.

39 A. Leśniak w artykule Problem formalnej analizy reprezentacji Zagłady... podkreślił: „Znaczenie przypisywane formie staje się jednak bardziej problematyczne, kiedy przyglądamy się temu, w jaki sposób mówi się o dziełach wizualnych i świadectwach obrazowych odnoszących się do Szoa” (A. Leśniak: Problem formalnej analizy reprezentacji Zagłady. „Obrazy mimo wszystko” Georgesa Didi-Hubermana i „Respite” Haruna Farockiego. „Teksty Drugie” 2010, nr 6, s. 155).

40 Premierę miał w Theatre Royal w Plymouth w lipcu 2007 r., na West Endzie - 19 listopada 2008 r., wersja filmowa drugiej produkcji powstała w 2010 r.

41 Por. B. Baszczak: Zakazana reprezentacja, niewyrażalność i milczenie. Jean-Luc Nancy i estetyzacja Zagłady. „Słupskie Studia Filozoficzne” 2012, nr 11, s. 71-85.

${ }^{42}$ M.P. Markowski: O reprezentacji. W: Kulturowa teoria literatury. Główne pojęcia i problemy. Red. M.P. Markowski, R. Nycz. Kraków 2006, s. 301. 
Do Żydów deportowanych do warszawskiego getta należą Warshowscy. Aktor Daniel Warshowsky, którego żona Hannah została pojmana przez nazistów, wraz z rodziną i przyjaciółmi tworzy grupę teatralną ${ }^{43}$. Podobnie jak w musicalu Korczak - po wglądzie w szczęśliwe czasy przedwojenne (otwierający utwór nosi tytuł Last Days of Summer) przenosimy się do roku 1942, do warszawskiego getta.

Janusz Korczak chętnie wspominał w sierocińcu o Masadzie, „mówił o walce narodowej przeciwko Rzymianom, opowiadał, jak długo w pustynno-górskiej twierdzy [...] bronili się Machabeusze [...]"44 - notował jego biograf Kazimierz Dębnicki. Daniel z Imagine This planuje wystawienie spektaklu zatytułowanego Masada, obrazującego oblężenie tej pustynnej twierdzy w roku 73 i masowe samobójstwo 960 Żydów. Warshowsky przekonuje rodzinę i przyjaciół do opowiedzenia o ich oporze $\mathrm{w}$ formie musicalu, choć wielu $\mathrm{z}$ warszawian śpiew i taniec przy podjęciu tego tematu wydają się naruszać decorum ${ }^{45}$.

Tytułowa piosenka, wybrzmiewająca raz jeszcze po mordzie aktorów podczas premiery ich spektaklu, zachęca do oddawania się marzeniom. Córka głównego bohatera, nosząca starotestamentowe imię synowej Abrahama - Rebeka, wątpi jednak w swoją wyobraźnię, a jej kwestia dźwięczy echem wspomnień Racheli Auerbach: „Jeśli nie widziałeś kwiatu przez dwa lata - o czym marzyć?"46. Członkowie grupy teatralnej wyznają: „Marzę o gorącej kąpieli”, „Ja o papierosie”. Daniel nagli wszystkich do kontynuowania: „Śpiewanie wolnym, czyni wolnym!"; i tu znów, jeśli pozwolić sobie na takie tłumaczenie, inna, złowieszcza formuła obozowa staje się ekwiwalentna syntaktycznie.

\section{Być zmianą Edukacja na rzecz pokoju}

Damian Aleksander, jeden z odtwórców tytułowej roli w musicalu Korczak, podkreślał, że spektakl ten pełnił prócz innych także funkcję edukacyjną ${ }^{47}$. Do

${ }^{43}$ Rebecca, córka Daniela, Leon, jego dziesięcioletni syn, Sarah, siostra głównego bohatera, oraz jej mąż Max, dalej: Adolph - ojciec Daniela i Sarah, oraz pozostali członkowie grupy aktorskiej: Izzy - komediant z Berlina, Otto - niemiecki aktor filmowy, Lola, Jan - syn rabina, Jacob - młody aktor, Adam - chłopak.

${ }^{44}$ K. DęBNicki: Korczak z bliska..., s. 165.

${ }^{45}$ Wystawiając spektakl o Masadzie, Daniel wcieli się w rolę Eleazara, przywódcy żydowskiej grupy, Rebecca - w jego córkę, Jan - w rolę Aarona, Adam - w rolę rzymskiego generała Silvy, Adolph - w rolę cesarza, a Izzy - Pompey, niewolnika ukrywającego chrześcijan, Otto w rolę trybuna Rufusa.

${ }^{46}$ R. Auerbach: Pisma $z$ getta warszawskiego. Przeł. K. Szymaniak. Warszawa 2016, s. $145-146$.

${ }^{47}$ https://www.youtube.com/watch?v=jNrrpOyS1wE\&t=231s [data dostępu: 18.11.2018]. 
słów Johna Lennona: „dajmy szansę pokojowi”, dopowiedziałabym: dajmy też szansę edukowaniu na rzecz pokoju. Imagine this, wyobraźmy sobie to: szkołę $\mathrm{z}$ systemowym nauczaniem propokojowym, szkołę, która, jak w systemie fińskim, zajęcia edukacji emocjonalnej wprowadza do programu od najwcześniejszych klas, lub w amerykańskim: często umożliwia dzieciom sytuację wystawiania przez nie spektakli, nierzadko musicali. Przypomnijmy w tym miejscu, że w 1999 roku nie kto inny, a amerykański nauczyciel historii Norman Conard z Uniontown zainspirował powstanie szkolnej sztuki teatralnej Life in a Jar (Życie $w$ słoiku) i tym samym prawdziwie rozpropagował dokonania Ireny Sendlerowej.

Jakie uczucia mieszkają i mieszają się w młodych widzach podczas spektakli Korczak czy Imagine This? Co można by dostrzec na obrazach rentgenowskich serc takich dzieci? Zapewne wzruszenie. A Stary Doktor powiedziałby im: „Zapamiętajcie na zawsze naukę płynącą z tego przeżycia”.

Spotkanie ze spektaklem - w tym z teatrem muzycznym - może stać się krokiem do zintegrowania wiedzy z emocją i do humanizacji wiedzy; uruchamia rezerwy empatii, zapewniając większą intymność spotkania $z$ tekstem i niesionymi przezeń prawdami niż w zdarzeniu edukacyjnym podczas zwyczajowej lekcji (zaciemnienie, możliwość wyłączenia się, brak poczucia, że jest się obserwowanym). Spektakl oferuje przestrzeń na zmianę emocji widza, na głęboką transformację myślenia, ustrzega przed zbyt pochopnym zadaniem pytania lub nadto pospiesznym komentarzem, pobudza przebudowę myślenia i nierzadko rozpoczyna proces wewnętrznej przemiany odbiorcy. Piosenka natomiast przy odbiorze tekstu emocjonalnie trudnego daje chwilowe wytchnienie, a odczuwana przez wielu widzów jej autentyczność pomieszana ze swoistą sztucznością zapewnia młodej publiczności psychiczny komfort.

Oglądając spektakl o niesprawiedliwości, ale i o pięknej współpracy oraz pomocy, młodzi widzowie marzą zapewne o tym, by doświadczyć podobnego wsparcia w czasach pokoju i spotkać takiego nauczyciela jak Korczak. Oba przywołane musicale integrują przeszłość (ucząc o historii Zagłady), teraźniejszość (dając prawdę o przeżyciu teatralnym) i przyszłość (wpływając na działania, myśli i marzenia widzów). Integralnymi częściami przeżycia w modelowym odbiorze winny być wszak niezgoda na niesprawiedliwość i chęć zapobiegania łamaniu praw człowieka, a w konsekwencji zadanie sobie pytania na kształt postawionego przez Gandhiego: jak być zmianą, którą chce się widzieć $\mathrm{w}$ świecie?

Ponadto, podczas poznawania tekstów o Holokauście rychło okaże się, jak zachłannie ich bohaterowie sięgają po opowieści: po tę o Masadzie, o szczurołapie z Hameln czy po Pocztę. Tym samym młody odbiorca otrzymuje ważną wiadomość o ocalającej roli literatury, teatru i piosenki. 


\section{Bibliografia}

Auerbach R.: Pisma z getta warszawskiego. Przeł. K. Szymaniak. Warszawa 2016.

BAszczak B.: Zakazana reprezentacja, niewyrażalność i milczenie. Jean-Luc Nancy i estetyzacja Zagłady. „Słupskie Studia Filozoficzne” 2012, nr 11, s. 71-85.

Bertisch R.: Niepowtarzalny pedagog. W: Wspomnienia o Januszu Korczaku. Wybór i oprac. L. BARszczewsKa, B. Milewicz. Warszawa 1981, s. 198-203.

Bielańska A.: Teatr, który leczy. Kraków 2002.

Boyne J.: Chłopiec w pasiastej piżamie. Przeł. P. Łopatka. Poznań 2017.

DęBNICKI K.: Korczak z bliska. Warszawa 1985.

Foster S. et al.: What Do Students Know and Understand about the Holocaust? Evidence from English Secondary Schools. London 2015.

Hannowa A.: Młodzież i teatr. Warszawa-Wrocław 1990.

Hartman S.: Janusz Korczak's Legacy: An Inestimable Source of Inspiration. In: J. Korczak: The Child's Right to Respect. Transl. E.P. Kulawiec. Strasbourg Cedex 2009, s. $13-22$.

Higher Education for Peace. Report. Conference in Tromso, 4-6 May 2000 (broszura, bez numeracji stron).

Hillman J.: Echoes of the Holocaust on the American Musical Stage. Jefferson 2012.

Holocaust Survivor, Peace Prize Winner Talks to Local High School and College Students. Dostępne w Internecie: https://www.daytondailynews.com/news/local/elie-wieselthe-answer-education-and-memory/XME3lf3TQTDmQmboHzDFuL/ [data dostępu: 18.11.2018].

Jansson T.: Lato Muminków. Przeł. I. Szuch-Wyszomirska. Warszawa 1967.

Jaromir A.: Ostatnie przedstawienie panny Esterki. Il. G. CichowskA. Poznań 2014.

KaniA A.: Lekcja (nie) obecności. Dziedzictwo polsko-żydowskie w edukacji polonistycznej. Kraków 2017.

Korczak J.: Pamiętnik $i$ inne pisma z getta. Przypisy M. Ciesielska. Posłowie J. LeoCIAK. Warszawa 2012.

Krupa B.: Czy zajęcia o Zagładzie moga/powinny być atrakcyjne. W: Auschwitz i Holokaust: dylematy i wyzwania polskiej edukacji. Red. P. Trojański. Oświęcim 2008, s. $213-221$.

Kwiatkowski M.: Uruchomić wyobraźnię. „Polonistyka” 1995, nr 9, s. 612-615.

LEeK J.: Pomiędzy porozumieniem a zrozumieniem. Wyzwania edukacji na rzecz pokoju. „Studia Dydaktyczne” 2014, T. 26, s. 247-257.

LeŚNIAK A.: Problem formalnej analizy reprezentacji Zagłady. "Obrazy mimo wszystko” Georgesa Didi-Hubermana i „Respite” Haruna Farockiego. „Teksty Drugie” 2010, nr 6, s. 155-166.

Markowski M.P.: O reprezentacji. W: Kulturowa teoria literatury. Główne pojęcia i problemy. Red. M.P. Markowski, R. NyCz. Kraków 2006, s. 287-334.

Miller R.: Z rozważań nad edukacja teatralną. „Kwartalnik Pedagogiczny” 1968, nr 3 (przedruk za: Więcej niż teatr. Sztuka zaangażowania i angażująca wychowawczo. Romany Miller inspiracje dla współczesnej pedagogiki. Red. M. SzczepsKa-Pustkowska, E. Rodziewicz. Gdańsk 2017, s. 58-76).

Olczak-Ronikier J.: Korczak. Próba biografii. Warszawa 2011. 
PANeK W.: Musical i rozrywkowy teatr muzyczny. „Wychowanie Muzyczne w Szkole” 1999, nr 1, s. 147-152.

Pearce A., Chapman A.: The Holocaust in the National Curriculum after 25 Years. "Holocaust Studies. A Journal of Culture and History" 2017, no 23, s. 225.

Pettigrew A. et al.: Teaching about the Holocaust in English Secondary Schools: An Empirical Study of National Trends, Perspectives and Practice. London 2009.

Robinson K., Aronica L.: Kreatywne szkoły. Oddolna rewolucja, która zmienia edukację. Przeł. A. BAJ. Kraków 2015.

Świontek S.: Dialog, dramat, metateatr. Z problemów teorii tekstu dramatycznego. Warszawa 1999.

Tagore R.: Poczta. Przeł. B. Gebarski. Posłowiem opatrzył R. Waksmund. Wrocław 1997.

Wąchоска E.: Teatr $w$ teatrze. W: Encyklopedia teatru polskiego. Dostępne w Internecie: http://www.encyklopediateatru.pl/hasla/180/teatr-w-teatrze [data dostępu: 18.11.2018].

Westin B.: Tove Jansson. Mama Muminków. Biografia. Przeł. B. Ratajczak. Warszawa 2012.

Wóscik-Dudek M.: W(y)czytać Zagładę. Praktyki postpamięci w polskiej literaturze XXI wieku dla dzieci i młodzieży. Katowice 2016.

ZACZYŃsKi W.P.: Uczenie się przez przeżywanie. Warszawa 1990.

Joanna Roszak

Singing the Unsingable?

The Position of the Musical in Holocaust Education

Summary

The author of the article focuses on the position and possibilities of theatre education - more specifically, the musical - in Holocaust education, which is a significant element of peace education. Wishing to widen the scope of Betty Reardon's tetrad which identifies the following foundations of ideal education for peace: personal, political, pedagogical, poetic, the author proposes to add one more "p" - performative. Two musicals interpreted in the article, Imagine This and Korczak are convergent in multiple aspects; among others, both share the motif of theatre within theatre, and their location is the Warsaw ghetto of 1942 .

Key words: musical, peace education, Holocaust education, Korczak 